AL-IQTISHOD: Jurnal Pemikiran dan Penelitian Ekonomi Islam

E-ISSN: 2745-85I2 P-ISSN: 2407-6600

Volume 9 Issue 2 Juli 202I | Page: I-I8

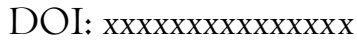

\title{
Pengaruh Tingkat Suku Bunga Federal Reserve Dan Nilai Tukar Rupiah Terhadap Jakarta Islamic Index
}

\author{
Ahmad Fatoni \\ Jurusan Ekonomi Syariah Universitas Sultan Ageng Tirtayasa \\ ahmadfatoni@untirta.ac.id
}

\begin{abstract}
Jakarta Islamic Index (III) on progress to wards the Islamic capital market face many obstacles. One of them is the practice of speculation made by investors who are not genuine (not genuine investors). External factors that can be used as an indicator of investor speculation is the interest rate and the exchange rate. This study aims to determine the impact of interest rate fluctuations federal reserve and the exchange rate of the Jakarta Islamic Index. The data used is secondary data in the form of monthly time series period January 2007 to June 20I6. The source of data obtained from Federal Reserve, Bank Indonesia, and Indonesia Stock Exchange (IDX). Analysis of data using Vector Auto Regression (VAR) with Impulse Response techniques. The analysis showed that fluctuations in Jakarta Islamic Index (JII) was influenced by the federal reserve interest rate and the exchange rate. It thus indicates that there is still a speculative practice done by the investor. As a solution to prevent speculation is to establish a minimum holding period or minimum stock holding period.
\end{abstract}

Keywords: Federal Reserve Interest Rate, Rupiah Exchange Rate, Jakarta Islamic Index (III)

Abstrak: Perkembangan Jakarta Islamic Index (III) menuju pasar modal syariah menghadapi banyak kendala. Salah satunya adalah praktik spekulasi yang dilakukan oleh investor yang tidak asli (not genuine investor). Faktor eksternal yang dapat dijadikan indikator spekulasi investor adalah tingkat suku bunga dan nilai tukar. Penelitian ini bertujuan untuk mengetahui pengaruh fluktuasi suku bunga federal reserve dan nilai tukar Jakarta Islamic Index. Data yang digunakan adalah data sekunder berupa time series bulanan periode Januari 2007 sampai Juni 20I6. Sumber data diperoleh dari Federal Reserve, Bank Indonesia, dan Bursa Efek Indonesia (BEI). Analisis data menggunakan Vector Auto Regression (VAR) dengan teknik Impulse Response. Hasil analisis menunjukkan bahwa fluktuasi Jakarta Islamic Index (III) dipengaruhi oleh suku bunga federal reserve dan nilai tukar. Hal ini mengindikasikan masih adanya praktik spekulatif yang dilakukan oleh investor. Sebagai solusi untuk mencegah spekulasi adalah dengan menetapkan minimum holding period atau minimum stock holding period.

Kata Kunci: Suku Bunga Federal Reserve, Nilai Tukar Rupiah, Jakarta Islamic Index (III) 



\section{A. Pendahuluan}

Pasar modal islami adalah konsep yang mendorong agar pasar modal menjadi tempat investasi yang sesungguhnya dan tidak tercampur dengan aktivitas spekulasi. Khan (1992) menyoroti adanya investor yang tidak asli (not genuine investor) yang sering disebut spekulator. Spekulator berusaha mendapat untung dengan memanfaatkan fluktuasi harga saham. Mereka membeli saham yang diperkirakan akan naik dalam waktu dekat dan akan menjualnya setelah harga naik. Dasar analisis yang digunakan untuk memprediksi apakah harga saham akan naik atau turun memang dapat berasal dari informasi fundamental yang relevan dan terpercaya, namun sering juga yang bersumber dari rumor atau isu. Ulah spekulator ini telah menjadi pemicu sejumlah krisis di pasar modal seperti yang terjadi di Amerika Serikat baik pada tahun I930 maupun pada 1987.

Indonesia sebagai Negara muslim terbesar didunia telah menerapkan pasar modal berbasis syariah. Munculnya produk syariah di pasar modal pada mulanya berawal dari keinginan untuk mengakomodasi kebutuhan umat islamyang ingin berinvestasi dengan prinsip syariah. Hal ini lah yang kemudian melatarbelakangi PT Danareksa Investment Management untuk meluncurkan Danareksa Syariah pada tanggal 3 Juli 1997. Kemudian pada tanggal 3 Juli 2000 Bursa Efek Indonesia bekerjasama dengan PT Danareksa Investment Management meluncurkan Jakarta Islamic Index. JII merupakan indeks yang berisi dengan 30 saham perusahaan yang memenuhi kriteria investasi berdasarkan syariah islam. (Jogiyanto Hartono, 2016:158).

Namun demikian ada beberapa kriteria yang harus dipenuhi untuk menentukan saham tersebut tergolong saham syariah atau tidak. Kriteria tersebut meliputi kriteria yang bersifat kulaitatif yakni melihat dari kegiatan perusahaan apakah sesuai dengan prinsip syariah dan kriteria kuantitatif yakni hutang berbasis bunga disbanding total asset tidak lebih dari $45 \%$ dan total pendapatan non halal dibanding total pendapatan tidak lebih dari I0\%. Screening syariah terhadap emiten telah diterapkan pada pasar

\section{Volume. 9/No. 2/Juli 202I Al-Iqtishod | I}


Pengaruh Tingkat Suku Bunga ....

modal syariah, namun demikian tidak sama hal-nya dengan etika bisnis untuk mencegah spekulasi.

Etika bisnis yang berdasarkan prinsip syariah hanya sebatas konsep dan belum diterapkan. Para investor masih berpotensi untuk melakukan spekulasi, salah satunya adalah suku bunga federal reserve. Jika suku bunga bank sentral Amerika Serikat (federal reserve) naik maka sektor perbankan akan turut menaikkan suku bunga simpanan, yang berimbas adanya pemindahan dana dari pasar modal ke bank. Hal demikian memungkinkan investor memindahkan dananya dari Indonesia kembali ke Amerika Serikat. Hal ini menyebabkan indeks harga saham akan mengalami penurunan. Selain itu pengalihan dana mereka terhadap investasi lainya akan berdampak pada rupiah yang terdepresiasi.Untuk membuktikan hipotesis tersebut maka dalam penelitian ini penulis mengangkat judul dampak fluktuasi tingkat suku bunga federal reseve dan nilai tukar rupiah terhadap Jakarta Islamic Index.

\section{B. Kajian Pustaka}

\section{Jakarta Islamic Index (JII)}

Suatu index diperlukan sebagai sebuah indicator untuk mengamati pergerakan harga dari sekuritas-sekuritas salah satunya adalah Jakarta Islamic Index (JII). JII dibuat oleh BEI bekerjasama dengan PT Danareksa Investment Management dan diluncurkan pada tanggal 3 Juli 2000. JII menggunakan basis tanggal Januari 1995 dengan nilai awal sebesar I00. JII diperbarui setiap 6 bulan sekali yaitu pada awal bulan Januari dan Juli.

JII merupakan indeks yang berisi dengan 30 saham perusahaan yang memenuhi kriteria investasi berdasarkan syariah islam, dengan prosedur sebagai berikut:

a) Saham dipilih harus sudah tercatat paling tidak 3 bulan terakhir, kecuali saham yang termasuk dalam IO kapitalisasi besar 
b) Mempunyai rasio utang terhadap aktiva tidak lebih dari $90 \%$ di laporan keuangan tahunan atau tengah tahun.

c) Dari yang masuk kriteria nomor I dan 2, dipilih 60 saham dengan urutan rata-rata kapitalisasi pasar terbesar selama satu tahun terakhir.

d) Kemudian dipilih 30 saham dengan urutan tingkat likuiditas rata-rata nilai perdagangan regular selama 3 tahun terakhir. (Jogiyanto Hartono, 20I6:I 58)

\section{Hubungan Tingkat Suku Bunga Terhadap JII}

Menurut Lipsey, Ragan, Courant (I997:47I), suku bunga adalah harga yang dibayarkan untuk satuan mata uang yang dipinjam pada periode waktu tertentu. dan suku bunga rill adalah selisih antara suku bunga nominal dengan laju inflasi. Sedangkan suku bunga nominal adalah rasio antara jumlah uang yang di bayarakan kembali dengan jumlah uang yang dipinjam.

Tingkat bunga mempengaruhi pasar saham dengan dua cara. Pertama, tingkat bunga mempengaruhi laba perusahaan. Semakin tinggi tingkat bunga, laba perusahaan akan semakin berkurang karena di pergunakan untuk membayar bunga yang tinggi. Kedua, tingkat bunga yang tinggi akan menyebabkan investor menarik investasi sahamnya dan memindahkannya pada investasi yang menawarkan hasil pengembalian yang lebih baik, seperti obligasi atau deposito yang menawarkan tingkat bunga yang tinggi. Hal ini akan menyebabkan harga menjadi turun. Yang pada akhirnya dapat meminimkan return yang di peroleh seorang investor.

Banyak investor yang mendasarkan keputusan investasinya kepada informasi perekonomian Amerika Serikat. Salah satu informasi yang dijadikan dasar pengambilan keputusan investasi adalah pergerakan suku bunga bank sentral Amerika Serikat (The fed). Jika suku bunga bank sentral Amerika Serikat naik maka sektor perbankan akan turut menaikkan suku bunga simpanan, yang berimbas adanya pemindahan dana dari pasar modal ke bank.Itu memungkinkan investor memindahkan dananya dari Indonesia kembali ke Amerika Serikat.Hal ini menyebabkan indeks harga saham akan mengalami penurunan (Surbakti,20I I).

Volume. 9/No. 2/Juli 202I A1-Iqtishod|3 
Pengaruh Tingkat Suku Bunga ....

\section{Hubungan Nilai Tukar Rupiah terhadap JII}

Perubahan nilai tukar mempengaruhi daya saing internasional dan neraca perdagangan yang berdampak pada pendapatan rill dan output (Dombush dan Fischer, 1980 dalam Cipollini dkk, 2008). Perubahan pendapatan dan output akan berpengaruh terhadap keputusan investasi dan konsumsi saat ini. Ketika nilai rupiah terdepresiasi maka harga bahan baku yang di impor akan mahal yang kemudian akan mempengaruhi kenaikan bahan baku produksi dan akan mengurangi keuntungan perusahaan. Hal ini yang mengakibatkan terjadinya penurunan harga saham yang selanjutnya akan menurunkan indeks JII.

Kurs rupiah merupakan perbandingan nilai mata uang rupiah dengan nilai mata uang negara lain. Jika diformulasikan kurs rupiah terhadap dolar artinya rupiah yang diperlukan untuk membeli satu dolar.Apabila kurs rupiah meningkat artinya rupiah mengalami depresiasi (melemah) sedangkan jika kurs rupiah menurun artinya rupiah mengalami apresiasi (menguat).

Nilai kurs rupiah terhadap dolar menjadi hal penting bagi perusahaan yang melakukan kegiatan ekspor dan impor. Jika nilai rupiah mengalami depresiasi akan membuat hargabarang impor naik dan biaya perusahaan yang menggunakan bahan baku impor akan mengalami kenaikan yang berimbas pada turunnya keuntungan.Turunnya tingkat keuntungan membuat investor kurang tertarik untuk berinvestasi pada saham perusahaan tersebut. Hal ini juga akan berpengaruh pada indeks harga saham yang akan mengalami penurunan (Witjaksono,2010).

\section{Metode Penelitian}

\section{Jenis dan Sumber Data}

Jenis data yang digunakan adalah data sekunder berupa time series bulanan periode Januari 2007 sampai dengan Juni 2016. Sumber data didapat dari Federal Reserve, Bank Indonesia, dan Indonesia Stock Exchange (IDX). 


\section{Metode Penelitian}

Vector Autoregression Model adalah model persamaan regresi yang menggunakan data time series. Persoalan yang muncul didalam data time series berkaitan dengan stasionaritas data time series dan kointegrasi. Pembentukan model VAR ini juga sangat terkait erat dengan masalah stasioneritas data dan kointegrasi antar variabel didalamnya.

Langkah pertama pembentukan model VAR adalah melakukan uji stasionaritas data. Jika data adalah stasioner pada tingkat level maka kita mempunyai model VAR biasa (unrestricted VAR). Sebaliknya jika data tidak stasioner pada level tetapi stasioner pada prose diferensi data, maka kita harus menguji apakah data mempunyai hubungan dalam jangka panjang atau tidak dengan melakukan uji kointegrasi. Apabila terdapat kointegrasi maka model yang kita punyai adalah model Vector Eror Correction Model (VECM). Model VECM ini merupakan model yang terestriksi (restricted VAR) karena adanya kointegrasi yang menunjukkan adanya hubungan jangka panjang antar variabel didalam system VAR. Namun demikian apabila data stasioner pada proses diferensi tetapi variabel tidak terkointegrasi maka disebut model VAR dengan data diferensi (VAR indifference). (Agus Widarjono, 2016:334)

a. Uji Stasionaritas Data

Uji stasionaritas data bisa dilakukan dengan menggunakan uji akar unit Augmented Dickey Fuller (ADF) atau Philips Perron (PP) atau dengan uji yang lain sesuai dengan bentuk tren yang terkandung pada setiap variabel. Hasil uji ADF dan PP atau yang lain sangat dipengaruhi oleh panjangnya kelambanan. Panjangnya kelambanan tersebut bisa dilakukan melalui pemilihan lag optimum. (Agus Widarjono, 2016:334) 
Pengaruh Tingkat Suku Bunga ....

b. Pemilihan Lag Optimum

Dalam VAR penentuan lag optimal sangat penting karena penentuan lag optimal berguna untuk menghilangkan masalah autokorelasi dalam sebuah sistem VAR. Penentuan lag optimal juga berguna untuk menunjukkan berapa lama reaksi suatu variabel terhadap variabel lainnya (Gustiani, et.al dalam Malahayati, 20II). Pemilihan Ordo atau lag dilakukan berdasarkan kriteria Akaike Information Criterion (AIC) danSchwarz Information Criterion (SC). Lag yang dipilih adalah model dengan nilai AIC dan SC terkecil

c. Uji Kointegrasi

Sebagaimana dinyatakan oleh Engle-Granger (1983) keberadaan variabel nonstasioner menyebabkan kemungkinan besar adanya hubungan jangka panjang adanya variabel dalam sistemVAR. Uji kointegrasi dapat mengetahui model merupakan VAR tingkat diferensi jika tidak ada kointegrasi dan VECM bila terdapat kointegrasi. (Agus Widarjono, 2016:337)

d. Uji Stabilitas

Stabilitas dalam system VAR perlu diperhatikan dalam penentuan lag. Stabilitas VAR dapat dilihat dari nilai inverse roots karakteristik AR polinominalnya. Suatu system VAR dikaakan stabil apabila seluruh roots pada table AR roots-nya memiliki modulus lebih kecil dari satu dan semuanya terletak didalam unit circle.

e. Impulse Response

Karena secara individual koefisien didalam model VAR sulit diinterpretasikan maka para ahli ekonometrika menggunakan analisis impulse Response. Impulse response ini merupakan salah satu analisis penting didalam model VAR. Analisis impulse response ini melacak respon dari variabel 
endogen didalam system VAR karena adanya goncangan (shocks) atau perubahan didalam variabel gangguan.(Agus Widarjono, 2016:339)

f. Variance Decomposition

Selain impulse response, model VAR juga menyediakan analisis forecast eror decomposition of variance atau sering kali disebut dengan variance decomposition. Variance decomposition ini memberikan metode yang berbeda didalam menggambarkan system dinamis VAR dibandingkan dengan analisis impulse response sebelumnya. Analisis variance decomposition menggambarkan relative pentingnya setiap variabel dalam system VAR karena adanya shock. Variance docomposition berguna untuk memprediksi kontribusi prosentase varian setiap variabel karena adanya perubahan variabel tertentu didalam system VAR. (Agus Widarjono, 2016:342)

\section{Hasil dan Pembahasan}

\section{Uji Stasioneritas Data}

Uji stasioneritas data merupakan tahap yang penting dalam menganalisis data time series. Uji stasioneritas data dalam hal ini menggunakan uji akar unit dengan hasil sebagai berikut:

\section{Tabel I Hasil Uji Stasioneritas Data}

\begin{tabular}{|l|r|l|r|r|}
\hline \multirow{2}{*}{ Variabel } & \multicolumn{2}{|c|}{ Level } & \multicolumn{2}{c|}{ First Difference } \\
\cline { 2 - 5 } & ADF-statistic & t-statistic & ADF-Statistic & t-statistic \\
\hline LOG (JII) & 0.943266 & -1.943688 & -8.486785 & -2.887425 \\
\hline LOG & & & & \\
(FEDRATE) & -0.979253 & $-1.9437 \mathrm{I} 4$ & -6.916069 & -2.887425 \\
\hline LOG(KURS) & $\mathrm{I} .284019$ & -1.943688 & $-9.4 \mathrm{II} 466$ & -2.887425 \\
\hline
\end{tabular}

Hasil uji stasioneritas data pada tingkat level menunjukkan bahwa semua variabel tidak stasioner pada taraf nyata 5\%. Hal ini dikarenakan nilai mutlak 
Pengaruh Tingkat Suku Bunga ....

ADF-statistic lebih kecil dari t-statistic pada taraf nyata 5\%. Pnelitian dengan data yang tidak stasioner dapat menghasilkan regresi palsu (spurious regression). Karena itu uji stasioneritas dilanjutkan pada tingkat First Difference. Hasil uji stasioneritas pada tingkat First Difference menunjukkan bahwa semua variabel dalam penelitian telah stasioner pada taraf nyata 5\%. Hal ini dikarenakan nilai mutlak ADFstatistic lebih besar dari nilai mutlak t-statistiknya pada taraf nyata $5 \%$.

Tabel 2 Hasil Uji Lag Optimum

\begin{tabular}{|c|c|c|}
\hline LAG & AIC & SC \\
\hline 0 & 33.00997 & 33.08535 \\
\hline I & 22.73355 & 23.03507 \\
\hline 2 & $22.47290^{*}$ & $23.00056^{*}$ \\
\hline 3 & $22.5157 \mathrm{I}$ & $23.2695 \mathrm{I}$ \\
\hline 4 & $22.60 \mathrm{I} 49$ & $23.58 \mathrm{I} 44$ \\
\hline
\end{tabular}

Catatan: Tanda " menunjukkan angka terkecil

Dalam model VAR penentuan lag optimum sangat berguna untuk menghilangkan autokorelasi. Berdasarkan hasil uji lag optimum pada tabel diatas, pengujian lag optimum baik pada kriteria Akaike Information Criteria (AIC) maupun Schwarz Information Criterion (SC) maka didapatkan panjang kelambanan pada lag ke-2.

Tabel 3 Hasil Uji Stabilitas

\begin{tabular}{|l|c|}
\hline \multicolumn{1}{|c|}{ Root } & Modulus \\
\hline $0.989632-0.009 \mathrm{I} 09 \mathrm{i}$ & 0.989674 \\
\hline $0.989632+0.009 \mathrm{I09i}$ & 0.989674 \\
\hline $0.873 \mathrm{I} 79$ & 0.873179 \\
\hline 0.385336 & 0.385336 \\
\hline $0.025546-0.2 \mathrm{I} 5397 \mathrm{i}$ & $0.2 \mathrm{I} 6907$ \\
\hline $0.025546+0.2 \mathrm{I} 5397 \mathrm{i}$ & $0.2 \mathrm{I} 6907$ \\
\hline
\end{tabular}

8| Al-Iqtishod Volume. 9/No. 2/Juli 202I 


\begin{tabular}{|l|}
\hline No root lies outside the unit circle. \\
\hline VAR satisfies the stability condition. \\
\hline
\end{tabular}

Model VAR dianggap stabil apabila seluruh roots-nya memiliki modulus lebih kecil dari satu dan berada dalam unit circle. Dari hasil uji stabilitas VAR, dapat disimpulkan bahwa sistem VAR bersifat stabil karena root yang diuji kurang dari satu yaitu berkisar antara 0.989674-0.2I6907.

Tabel 4 Hasil Uji Kointegrasi Johansen

\begin{tabular}{|c|c|c|c|c|}
\hline \multicolumn{4}{|c|}{ Unrestricted Cointegration Rank Test (Trace) } & \\
\hline Hypothesized & & Trace & 0.05 & \\
\hline No. of CE(s) & Eigenvalue & Statistic & Critical Value & Prob. \\
\hline None & 0.121096 & $20.973 \mathrm{I} 2$ & 29.79707 & 0.3593 \\
\hline At most I & $0.0576 \mathrm{I} 2$ & 6.645280 & I5.4947I & 0.6192 \\
\hline At most 2 & 0.000529 & 0.058704 & 3.841466 & 0.8085 \\
\hline \multicolumn{5}{|c|}{ Trace test indicates no cointegration at the 0.05 level } \\
\hline \multicolumn{5}{|c|}{ denotes rejection of the hypothesis at the 0.05 level } \\
\hline \multicolumn{4}{|c|}{${ }^{M}$ MacKinnon-Haug-Michelis (1999) p-values } & \\
\hline \multicolumn{5}{|c|}{ Unrestricted Cointegration Rank Test (Maximum Eigenvalue) } \\
\hline Hypothesized & & Max-Eigen & 0.05 & \\
\hline No. of CE(s) & Eigenvalue & Statistic & Critical Value & Prob. \\
\hline None & 0.121096 & $\mathrm{I} 4.32784$ & 2I.I3I 62 & 0.3387 \\
\hline At most I & $0.0576 \mathrm{I} 2$ & 6.586576 & $\mathrm{I} 4.26460$ & $0.539 \mathrm{I}$ \\
\hline At most 2 & 0.000529 & 0.058704 & $3.84 \mathrm{I} 466$ & 0.8085 \\
\hline
\end{tabular}

Volume. 9/No. 2/Juli 202I Al-Iqtishod |9 
Pengaruh Tingkat Suku Bunga ....

\begin{tabular}{|l|l|}
\hline Max-eigenvalue test indicates no cointegration at the 0.05 level \\
\hline denotes rejection of the hypothesis at the 0.05 level & \\
\hline MacKinnon-Haug-Michelis (I999) p-values & \\
\hline
\end{tabular}

Ketika semua variabel telah stasioner pada tingkatFirst Difference sehingga uji kointegrasi melalui Johansen Cointegrassion Test dapat dilakukan.Dari hasil uji kointegrasi Johansen menunjukkan bahwa model tidak terdapat kointegrasi sehingga model tergolong dalam jenis VAR Indifference.Hasil estimasi VAR seringkali tidak memuaskan dilihat dari uji t. Kelambanan variabel endogen didalam sistem VAR kemungkinan tidak signifikan secara statistik. Selain itu secara individual koefisien didalam model VAR sulit diinterpretasikan. Untuk itu digunakan analisis Impuls Response guna melihat goncangan (shock) didalam variabel. (Agus Widarjono: 339

\section{Gambar 2Respon Pergerakan JII Terhadap ShockFed Rate}

Response of LOG(JII) to LOG(FEDRATE)

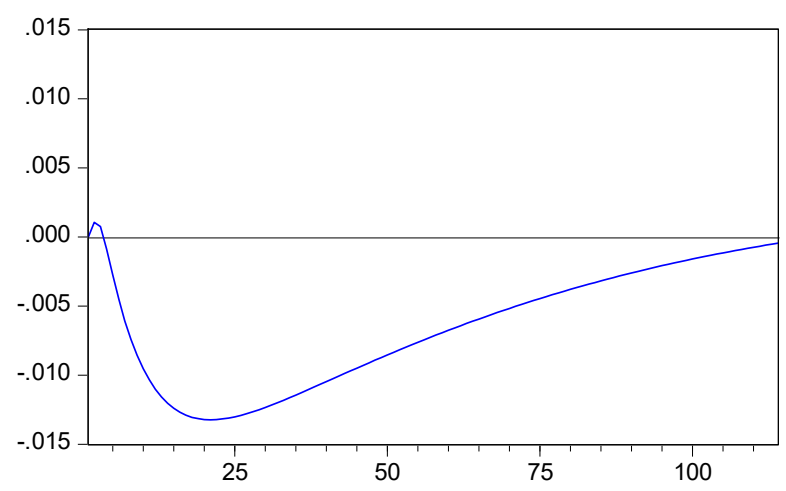

Ketika terjadi guncangan (shock) Fed Rate, pada periode kedua dan ketiga JII merespon positif. Namun demikian setelah periode kedua dan ketiga JII merespon negatif. Respon negatif JII akibat dari shock yang diterima dari Fed Rate menunjukkan puncaknya pada periode ke dua puluh satu yakni sebesar -0.013234. Respon negatif JII ini lebih disebabkan oleh adanya ketertarikan para investor JII terhadap imbal hasil Fed Rate yang lebih baik. Ketertarikan pada imbal hasil yang 
lebih baik ini memicu aksi jual oleh para investor dan mengalihkanya pada investasi lain sehingga mengakibatkan indeks JII menurun.

Namun demikian jika melihat pada tabel impulse respons pergerakan JII terhadap shock Fed Rate menunjukkan periode ke arah kestabilan meskipun respon JII masih tetap negatif. Hal demikian sesuai dengan data Fed Rate yang terus berupaya dalam menurunkan tingkat suku bunganya sehingga para investor JII menunjukkan reaksi yang tidak cukup tinggi. Meskipun masih terdapat para investor JII yang tertarik terhadap Fed Rate namun reaksinya tidak seperti pada periode sebelumnya.

\section{Gambar 3}

\section{Respons Pergerakan JII Terhadap Shock Nilai Tukar Rupiah}

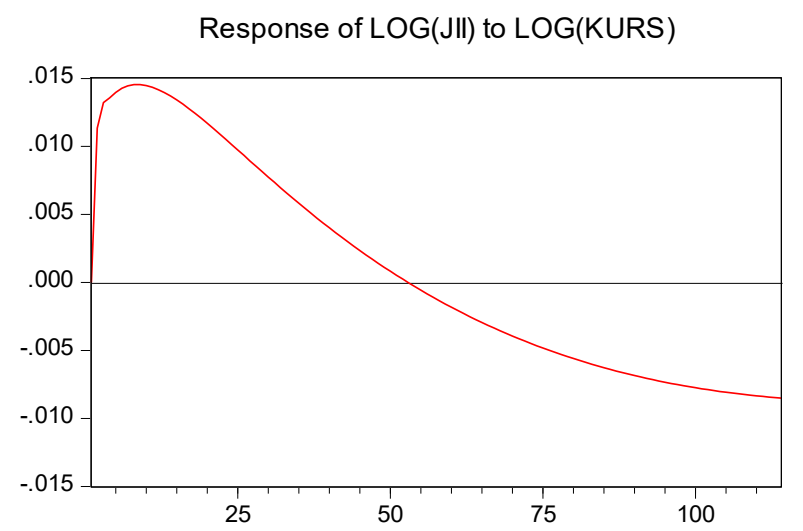

Impulse response diatas menunjukkan bahwa pada periode ke-I hingga periode ke-52, JII merespon positif terhadap gejolak nilai tukar rupiah. Hal demikian disebabkan adanya kepercayaan para investor terhadap nilai tukar rupiah sehingga mereka tidak mengalihkan investasinya. Namun demikian guncangan yang terjadi pada nilai tukar rupiah setelah periode ke-52, JII merespon secara negatif. Kekhawatiran investor terhadap ketidakpastian nilai tukar rupiah membuat mereka melakukan aksi jual dan mengalihkan dana pada investasi lainya. Hal demikian menyebabkan indeks JII menurun. Nilai kurs rupiah terhadap dolar menjadi hal penting bagi perusahaan yang melakukan kegiatan ekspor dan impor. 
Pengaruh Tingkat Suku Bunga ....

Jika nilai rupiah mengalami depresiasi akan membuat harga barang impor naik dan biaya perusahaan yang menggunakan bahan baku impor akan mengalami kenaikan yang berimbas pada turunnya keuntungan. Turunnya tingkat keuntungan membuat investor kurang tertarik untuk berinvestasi pada saham perusahaan tersebut.

\section{Gambar 4}

Response Pergerakan Nilai Tukar Rupiah Terhadap Shock Fed Rate

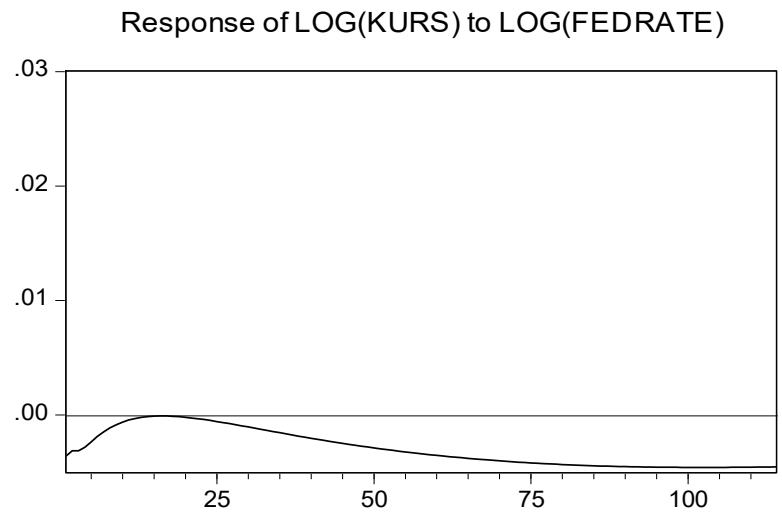

Guncangan (shock) yang terjadi pada fed rate direspon negatif oleh nilai tukar rupiah. Pada periode pertama nilai tukar rupiah merespon negatif yakni sebesar -0.00359. Namun demikian pada periode ke-I I (-0.0004) hingga periode ke-I5 (-0.000I) nilai tukar cenderung stabil meskipun direspon negatif. Kemudian setelah periode ke-I5 respon negatif nilai tukar rupiah akibat guncangan fed red terus meningkat. Respon negatif nilai tukar rupiah akibat guncangan yang terjadi pada fed rate disebabkan reaksi investor terhadap fluktuasi fed rate. Ketika the fed meningkatkan suku bunga maka yang akan terjadi adalah para investor akan menjual rupiah sehingga menyebabkan nilai tukar rupiah terdepresiasi. 


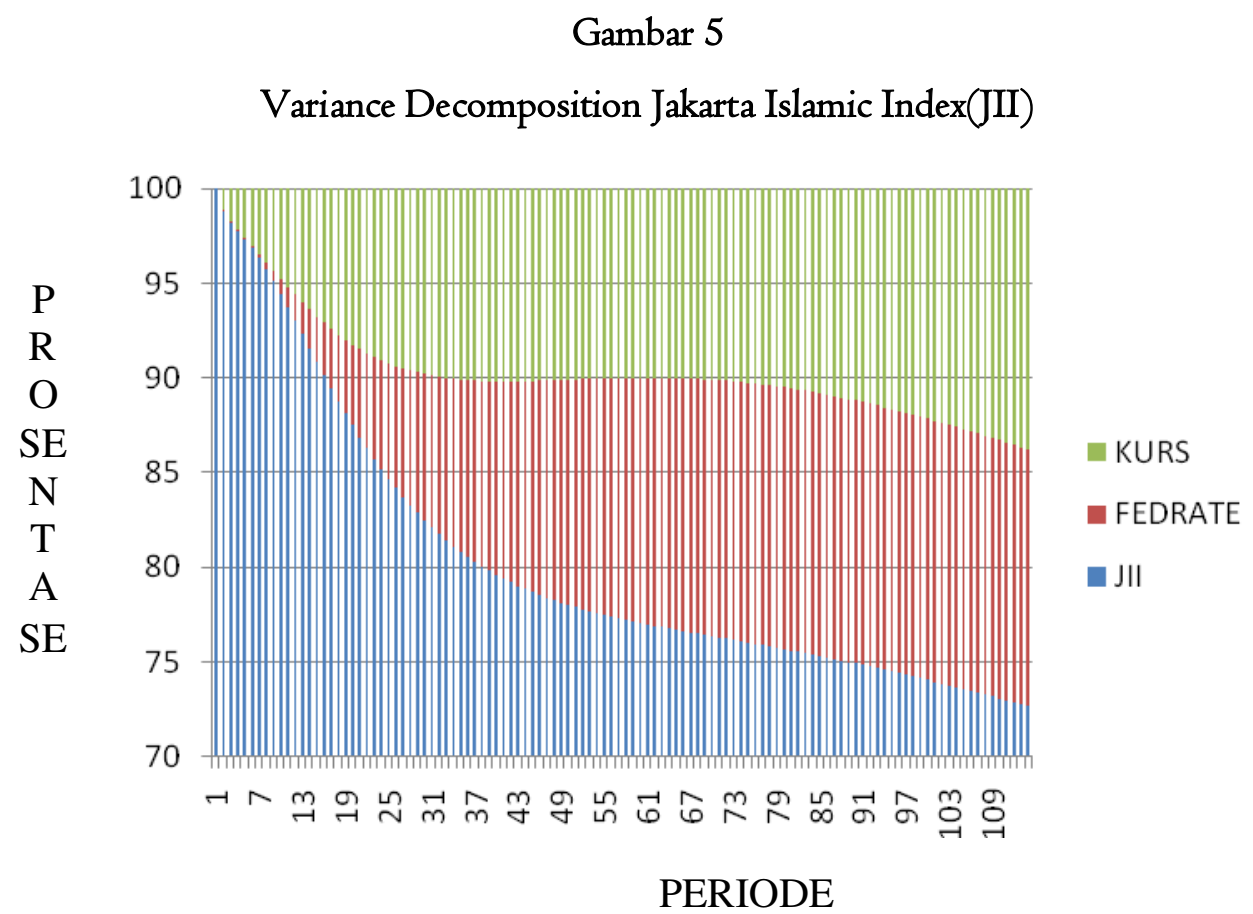

Dari hasil variance decomposition JII terlihat bahwa pada bulan ke-I, kontribusi terhadap keragaman (variability) indeks JII I00\% berasal dari JII itu sendiri. Prosentase ini kemudian mengalami penurunan secara bertahap hingga akhir periode pengamatan. Kemudian hasil variance decomposition nilai tukar rupiah pada bulan ke-2 yakni sebesar I.I0\% menunjukkan kontribusi terhadap keragaman JII yang lebih besar dari fed rate yakni sebesar 0.00, hingga pada bulan ke-39 variance decomposition nilai tukar masih menunjukkan hasil yang lebih besar daripada fed rate. Namun demikian hasil variance decomposition fed rate terhadap keragaman indeks JII pada periode pengamatan ke-40 (I0.23\%) dan periode ke-45 (II.I5\%), dimana nilai tersebut menunjukkan hasil yang lebih besar daripada variance decomposition nilai tukar rupiah pada periode pengamatan yang sama sebesar $10.17 \%$ dan $10.16 \%$. Hal yang menarik dari hasil ini adalah masih besarnya kontribusi fed rate terhadap keberagaman JII. Ini menunjukkan perilaku investor yang tidak sepenuhnya loyalis syariah, sehingga mereka masih 
Pengaruh Tingkat Suku Bunga ....

membandingkan keuntungan berinvestasi di pasar modal syariah dengan investasi dengan imbalan suku bunga.

\section{Solusi Dalam Mengatasi Spekulasi Pada Pasar Modal Islam}

Pada pembahasan sebelumnya berdasarkan hasil impulse response, maka dapat diketahui bahwa pergerakan JII masih dipengaruhi oleh faktor suku bunga fed rate dan nilai tukar rupiah. Hal demikian mengindikasikan bahwa masih terdapat praktik spekulasi yang dilakukan oleh investor pada bursa JII. Spekulasi dilarang bukan karena ketidakpastian yang ada dihadapanya, melainkan cara orang menggunakan ketidakpastian tersebut. Manakala ia meninggalkan sesnse of responsibility dan rule of law-nya untuk memperoleh keuntungan semata dari adanya ketidakpastian, itulah yang dilarang dalam konsep gharar dan maysir dalam Islam. Al gharar dan maysir sendiri adalah konsep yang sangat berkaitan dengan mudharat, negative result, atau hazard. (Nurul Huda dan Mohamad Heykal,2013:209)

Di pasar modal, larangan Islam diatas mesti diimplementasikan dalam bentuk aturan main yang mencegah praktik spekulasi. Salah satunya adalah dengan menetapkan minimum holding period atau jangka waktu memegang saham minimum. Dengan aturan ini, saham tidak bisa diperjualbelikan setiap saat, sehingga meredam motivasi mencari untung dari pergerakan harga saham semata. Masalahnya, berapa lama minimum holding period yang masuk akal? Pembatasan itu memang meredam spekulasi, akan tetapi juga membuat investasi di pasar modal menjadi tidak likuid. Padahal bukan tidak mungkin seorang investor yang rasional betul-betul membutuhkan likuiditas mendadak sehingga harus mencairkan saham yang dipegangnya, sedangkan ia terhalang karena belum melewati masa minimum holding period-nya

Dalam hal ini Metwally (1992) menawarkan sebuah model perdagangan pasar modal islami yang mensyaratkan sejumlah hal. Syarat terpenting adalah 
bahwa perlu dibentuk management committee untuk menetapkan maximum share price (MSP) untuk setiap saham interval paling lambat tiga bulan. MSP adalah sama dengan total ekuitas dibagi dengan total lembar saham yang diterbitkan perusahaan. Management committee harus memastikan bahwa semua perusahaan yang tercatat di bursa menggunakan standar akuntansi yang benar dan perdagangan saham hanya boleh berlangsung satu minggu yakni setelah MSP ditetapkan.

Menurut Metwally (1992), model tersebut memenuhi syarat keislaman dari pasar modal. Model ini memberi kesempatan kepada pemegang saham untuk menjual sahamnya untuk memenuhi kebutuhan likuiditasnya dan pada saat yang bersamaan menjaga agar pemegang saham memiliki komitmen terhadap perusahaan paling tidak memegang saham selama tiga bulan. Spekulasi menjadi sulit dilakukan karena pemegang saham tidak dapat memperdagangkan saham setiap saat dan adanya batasan MSP.

Chapra (1992) kurang setuju dengan model pasar modal islami yang ditawarkan oleh Metwally. Pembatasan harga maksimum justru akan merugikan investor kecil karena jika prospek perusahaan naik mereka tidak dapat menjual lebih tinggi, sementara jika prospek perusahaan memburuk mereka terpaksa harus menjual harga dibawah MSP. Dasar penetapan MSP yang berbasis nilai ekuitas juga dianggap tidak tepat. Dua perusahaan yang memiliki ekuitas yang sama bahkan menjual produk yang sama bisa jadi memiliki harga saham yang berbeda karena permintaan atas produk dari kedua perusahaan tidak sama. Disamping itu dasar penetapan harga yang hanya merujuk pada ekuitas dianggap terlalu lemah karena harga saham juga dipengaruhi oleh prospek perusahaan. Alasan bahwa harga harus dibatasi juga dipertanyakan oleh Chapra, untuk kebutuhan pokok dimana pembeli tidak dapat menunggu hingga harga turun karena harus segera mengkonsumsi, maka penetapan harga maksimum dapat dibenarkan. Sementara dalam membeli saham, investor tidak harus membeli saham sekarang jika harganya dirasa terlalu tinggi. Untuk mengatasi ketidakstabilan harga saham dipasar modal, 
Pengaruh Tingkat Suku Bunga ....

Chapra (1992) menawarkan tiga hal, yaitu membatasi spekulasi, hanya membolehkan pembelian saham secara tunai (melarang margin trading), dan menghilangkan management malpractices. Salah satu bentuk spekulasi yang harus dihindari adalah aktivitas short selling.

El-Din (2002) memberikan usulan perlunya harga rujukan untuk membatasi spekulasi. Harga rujukan ini perlu ada karena di pasar modal ada informed namun ada juga investor yang uninformed. Investor yang unimformed cenderung bertindak spekulatif karena tidak mengetahui informasi dengan lengkap dan akurat. Adanya harga rujukan akan mengurangi kesenjangan informasi antara investor yang informed dan investor yang unimformed, pada akhirnya akan mengurangi bahkan menghilangkan spekulasi. Harga rujukan ini ditetapkan oleh sebuah lembaga yang beranggotakan para pakar di pasar modal, ekonomi, statistik, dan bidang ilmu lain yang relevan untuk menentukan harga rujukan yang handal.

Pada pasar modal syariah di Indonesia sebenarnya sudah menerapkan aturan untuk mecegah terjadinya praktik spekulasi.Pada pasar modal syariah di Indonesia saham yang sudah dibeli boleh ditransaksikan kembali meskipun settlement baru dilaksanakan pada $T+3$ sesuai prinsip Qabdh Hukmi. ${ }^{1}$ Namun demikian bukan berarti para investor tidak dapat melakukan praktik spekulasi. Hal ini dikarenakan peraturan pencegahan spekulasi hanya diberlakukan jika para investor melakukan transaksi melalui account berbasis syariah. Pada kenyataanya para investor masih dapat melakukan transaksi meskipun tidak melalui account berbasis syariah sehingga praktik spekulasi akan tebuka lebar. Untuk itu sudah seharusnya diterapkan peraturan yang hanya membolehkan transaksi pada pasar modal syariah yang hanya dapat dilakukan melalui account yang berbasis syariah sehingga praktik spekulasi dapat dihindari.

\footnotetext{
${ }^{1} Q$ abdh Hukmi adalah penguasaan komoditi di bursa oleh pembeli secara dokumen kepemilikan komoditi yang dibelinya baik berupa catatan elektronik maupun non elektronik
}

16| A1-Iqtishod Volume. 9/No. 2/Juli 202I 


\section{E. Simpulan}

Berdasarkan hasil impulse response, JII mengalami fluktuasi dalam merespon guncangan atau shock yang terjadi pada seluruh variabel. Respon pergerakan JII terhadap fed rate rata-rata menunjukkan respon yang negatif. Sementara itu respon pergerakan JII terhadap shock nilai tukar rupiah menunjukkan respon positif dan negatif. Respon pergerakan nilai tukar rupiah terhadap shock fed rate menunjukkan respon negatif.Berbagai variasi respon JII terhadap variabel fed rate dan nilai tukar rupiah menunjukkan reaksi para investor JII. Para investor JII masih dipengaruhi oleh investasi dengankeuntungan yang lebih besar dibandingkan jika mereka melakukan investasi pada JII. Hal demikian mengindikasikan masih terdapatnya unsur spekulasi pada pasar modal syariah khususnya di Jakarta Islamic Index.

Terdapat beberapa solusi dalam mencegah terjadinya praktik spekulasi pada pasar modal syariah. Metwally menawarkan solusi maximum share price (MSP) dan hanya membolehkan memperdagangkan saham setelah jangka waktu satu minggu. Sementara itu Chapra mempunyai solusi hanya membolehkan pembelian saham secara tunai (melarang margin trading), menghilangkan management malpractices dan harus menghindari praktik short selling. Sedangkan El-Din memberikan usulan perlunya harga rujukan untuk membatasi spekulasi. Pada pasar modal syariah di Indonesia telah berupaya mencegah terjadinya spekulasi yakni dengan hanya membolehkan memperdagangkan saham setelah $\mathrm{T}+3$ hari. Namun demikian bukan berarti para investor tidak dapat melakukan praktik spekulasi. Hal ini dikarenakan peraturan pencegahan spekulasi hanya diberlakukan jika para investor melakukan transaksi melalui account berbasis syariah. Pada kenyataanya para investor masih dapat melakukan transaksi meskipun tidak melalui account berbasis syariah sehingga praktik spekulasi akan terbuka lebar. 
Pengaruh Tingkat Suku Bunga ....

\section{F. Daftar Pustaka}

Chapra, U.M. I992. Comment on Metwally's "The Role of The Stock Exchange in an Islamic Economy", dalam Abod et al. 1992. An Introduction to Islamic Finance. Kuala Lumpur: Quill Publisher.

El-Din, S.E.I.T. 2002. Toward an Islamic Model of Stock Market. Journal of King Abdul Aziz University: Islamic Economics, I4(2): 3-29.

Hartono Jogiyanto. 2016. Teori Portofolio dan Analisis Investasi. Yogyakarta: BPPFEYOGYAKARTA

Huda Nurul, Mohamad Heykal, 2013, Lembaga Keuangan Islam: Tinjauan Teoretis dan Praktis, Jakarta: Kencana

Khan,A.M. 1992. Commodity Exchange and Stock Exchange in an Islamic Economy dalam abode et.al. 1992. An Introduction to Islamic Finance. Kuala Lumpur: Quill Publisher

Nafkir Muhammad. 2009. Bursa Efek dan Investasi Syariah. Jakarta: PT Serambi Ilmu Semesta.

Surbakti, Edhy Priyatna Anugrah. 20I I. "Pengaruh Non Farm Payroll, suku bunga bank sentral Amerika Serikat (The Fed), dan Indeks Nikkei 225 terhadap Indeks dari saham-saham perusahaan berbasisi Syariah di Jakarta Islamic Index". Jurnal Akuntansi,Vol. 3

Witjaksono, Ardian Agung. 2010. "Analisis Pengaruh Tingkat Suku Bunga SBI, Harga Minyak Dunia, Harga Emas Dunia, Kurs Rupiah, Indeks Nikkei 225, dan Indeks Dow Jones terhadap IHSG". Tesis tidak diterbitkan. Semarang: Universitas Diponegoro.

Widarjono Agus. 2016. Ekonometrika Pengantar dan Aplikasinya. Yogyakarta: UPP STIM YKPN 